\title{
Stakeholder Values Inform Indigenous Peoples' Governance and Management of a Former National Park in New Zealand
}

\author{
C.Y. Bataille ${ }^{1} \cdot$ K. Luke ${ }^{2} \cdot$ T. Kruger ${ }^{2} \cdot$ S. Malinen ${ }^{1} \cdot$ R.B. Allen ${ }^{3} \cdot$ A.L Whitehead $^{4} \cdot$ P.O.'B. Lyver ${ }^{5}$ (I)
}

Published online: 7 September 2020

(C) The Author(s) 2020

\begin{abstract}
The global emphasis on stakeholder engagement in protected area management has increased over the last three decades. Here we present key values of statutory and non-statutory stakeholder groups as they relate to their relationship with the former Te Urewera National Park (NP), New Zealand, which is now recognised as "a legal entity" with "all the rights, powers, duties, and liabilities of a legal person." Non-statutory stakeholders conveyed a close, personal connection to Te Urewera NP in terms of heritage and legacy, which include both consumptive (e.g., hunting; fishing) and non-consumptive use (e.g., sight-seeing, hiking, boating). In contrast, statutory stakeholders expressed a more distant and procedural relationship with the park. Both stakeholder groups perceived the possible transfer of ownership or governance of Te Urewera NP to Tūhoe (the Indigenous Māori peoples of the Te Urewera region) favourably and expressed a desire to be engaged in the future stewardship of the NP. Stakeholders considered the fostering of relations with Tūhoe and other stakeholder groups as important to nurturing and maintaining their links with the area in future. Importantly, common interests that emerge from these relationships can increase mutual understanding between cultures and willingness to collaborate. Moreover, we posit that the legal personhood status for protected areas will be a powerful tool for reconciling pluralistic values and enable deliberative processes and flexible modes of collaboration between Indigenous peoples and non-indigenous stakeholders.
\end{abstract}

Keywords Stakeholders $\cdot$ Values $\cdot$ Governance $\cdot$ Protected areas $\cdot$ Indigenous peoples $\cdot$ Māori $\cdot$ Te Urewera National Park $\cdot$ New Zealand

\section{Introduction}

Protected areas are widely used for conserving biodiversity and biophysical features (Johnson et al. 2017). Globally, it is

Electronic supplementary material The online version of this article (https://doi.org/10.1007/s10745-020-00170-4) contains supplementary material, which is available to authorized users.

P.O.'B. Lyver

lyverp@landcareresearch.co.nz

1 University of Canterbury, Private bag 4800, Christchurch 8140, New Zealand

2 Te Uru Taumatua, 12 Tūhoe Street, Tāneatua, Tāneatua 3191, New Zealand

38 Roblyn Place, Lincoln 7608, New Zealand

4 National Institute of Water and Atmospheric Research, 10 Kyle St, Riccarton, Christchurch 8011, New Zealand

5 Manaaki Whenua Landcare Research, PO Box 69040, Lincoln 7640, New Zealand estimated that 209,000 protected areas cover $15.4 \%$ of the world's terrestrial and inland water areas, and $3.4 \%$ of the oceans - the total area covering approximately 32 million $\mathrm{km}^{2}$ of the planet (Juffe-Bignoli et al. 2014). In the modern conservation movement, the momentum for protected area systems primarily emerged from a drive to protect the natural environment from exploitation and land use intensification (Chape et al. 2008). Even so, almost $40 \%$ of all protected areas $\left(\mathrm{km}^{2}\right)$ are being managed for sustainable use of resources (Juffe-Bignoli et al. 2014). While protected areas have delivered biodiversity protection in many parts of the world, in some instances these outcomes have not been measured or evaluated (Craigie et al. 2010; Barnes et al. 2016).

Lack of local community engagement in protected area governance and management can lead to the failure or diminished effectiveness of some protected areas (Wilshusen et al. 2002; Adams et al. 2004; West et al. 2006; Roe 2008; Blom et al. 2010). Local communities often see protected areas as 'fortresses' managed with statutory restrictions that subvert peoples' rights, activities, and responsibilities for the area (Oldfield 1988; Fiallo and Jacobson 1995; Neumann 1997; 
Khan and Bhagwat 2010). Benefits for local communities living around or within the boundaries of these areas have been highly variable (Dasmann 1984; Fiallo and Jacobson 1995; Borrini-Feyerabend et al. 2004; Schultz et al. 2011; Holmes 2013; Zorondo-Rodríguez 2019). Also, there are increasing concerns about the statutory processes used to establish and manage protected areas at the expense of Indigenous peoples and local communities (IPLC) (Aswani and Weiant 2004; Ruru 2008; Holmes 2013). For example, while a range of protected area tenures have been widely adopted by nations around the world, many of these areas were already under existing customary land management and systems of Indigenous peoples (Rights and Resources Initiative 2015). Therefore, new paradigms, tools, and frameworks (e.g., juristic personhood) for redefining relationships with protected areas that facilitate better benefit and burden-sharing across society are being explored (Franks et al. 2018; Studley and Bleisch 2018).

Globally, national parks are an important form of protected area, making up approximately $25 \%$ of the protected areas $\left(\mathrm{km}^{2}\right)$ that have been assigned an International Union for the Conservation of Nature Management Category (Juffe-Bignoli et al. 2014). The significance of national parks is deeply ingrained within the national consciousness of many societies. National parks were first gazetted in the nineteenth century by governments seeking to protect and utilise areas of perceived 'wilderness' as places for conservation, recreation, and tourism (e.g., USA, Australia, Canada, and New Zealand; Cleghorn 1861; Ruru 2012). In some countries, however, national parks were founded at the expense of IPLC, with land confiscations and resettlement programmes enabling their establishment (e.g., Poirier and Ostergren 2002; Ruru 2004, 2008; Parks Canada 2010). As a result, IPLC' values were often subordinate to and transposed by the dominant culture in the governance and management of those areas. Protected areas, including national parks, link strongly with peoples' identities, attachment to place, cultural heritage, and conservation, recreation, and economic values (Graham et al. 2003; Secretariat of the Convention on Biological Diversity 2008; Stolten et al. 2015). The plurality in how protected areas are valued within societies support the importance of their role and function, but it can also be a source of conflict between interest groups (Stolten et al. 2015; Mannetti et al. 2019). Equitable consideration of diverse value sets, among other priorities (e.g., cross-cultural understanding and communication) is therefore seen as a key component of effective protected area governance and management (Dovers et al. 2015).

In New Zealand (NZ), there are currently 13 national parks covering $28,881 \mathrm{~km}^{2}$, which is approximately a third of the country's protected area (Molloy 2015). Prior to 2014, Te
Urewera NP $\left(2126.73 \mathrm{~km}^{2}\right)$ was part of this collective. It was also the ancestral homeland of Tūhoe, a Māori tribal group whose traditional territory included the heavily forested Te Urewera mountain ranges in the North Island of NZ (Fig. 1; Binney 2009). Part of Tūhoe's Treaty of Waitangi ${ }^{1}$ claim that negotiations between the tribal group and the 'Crown' (a term signifying the highest or constitutional authority of government in NZ) sought to settle held that Tūhoe land was unjustly appropriated to establish a national park in 1954 (Coombes and Hill 2005). As a result of Tūhoe's treaty settlement and enactment of the Te Urewera Act 2014, Te Urewera ceased to be a national park (section 12) in July 2014, becoming "a legal entity" with "all the rights, powers, duties, and liabilities of a legal person" (s 11(1); New Zealand Government 2014). As far as we are aware it is the first national park in the world to be delisted.

As part of Tūhoe's Treaty of Waitangi pre-settlement process, the tribal authority mandated by the Tūhoe people to settle their claim with the Crown, Te Kotahi a Tūhoe (TKAT), consulted mostly non-Māori statutory and non-statutory stakeholder groups with connections to Te Urewera NP. Amend to TKAT recognised that many stakeholder groups had a close connection and experience with Te Urewera NP and they wanted to understand the nature of these relationships and the knowledge that the groups could potentially contribute to the future management of the area. Therefore, the first objective of our study is to identify values that conveyed the nature of the relationship that statutory and non-statutory stakeholders have with Te Urewera NP. Our second objective is to identify the values that each group desired to see enshrined in a possible future ownership and/or governance model with Tūhoe and the key cultural and environmental governance principles that could enable non-Tūhoe stakeholder values and aspirations to be realised. We also discuss the delisting of Te Urewera NP and its reclassification within a juristic personhood framework.

Values can be described as higher-order evaluative standards or "trans-situational goals that serve as guiding principles in the life of a person or group" (Schwartz et al. 2012: 665) that influence people's attitudes, their decision-making, and their behaviour (Rokeach 1973; Olson and Zanna 1993). Key values relevant to this study are those Indigenous and non-indigenous values Lyver et al. (2016) identified in relation restoration of a coastal forest in northern NZ. Many of these align closely with the

\footnotetext{
${ }^{1}$ The Treaty of Waitangi (Te Tiriti o Waitangi) was signed on 6 February 1840 by representatives of the British Crown and Māori chiefs. The Waitangi Tribunal is "a standing commission of inquiry, [which] makes recommendations on claims brought by Māori relating to legislation, policies, actions or omissions of the Crown that are alleged to breach the promises made in the Treaty of Waitangi" (Waitangi Tribunal 2018)
} 


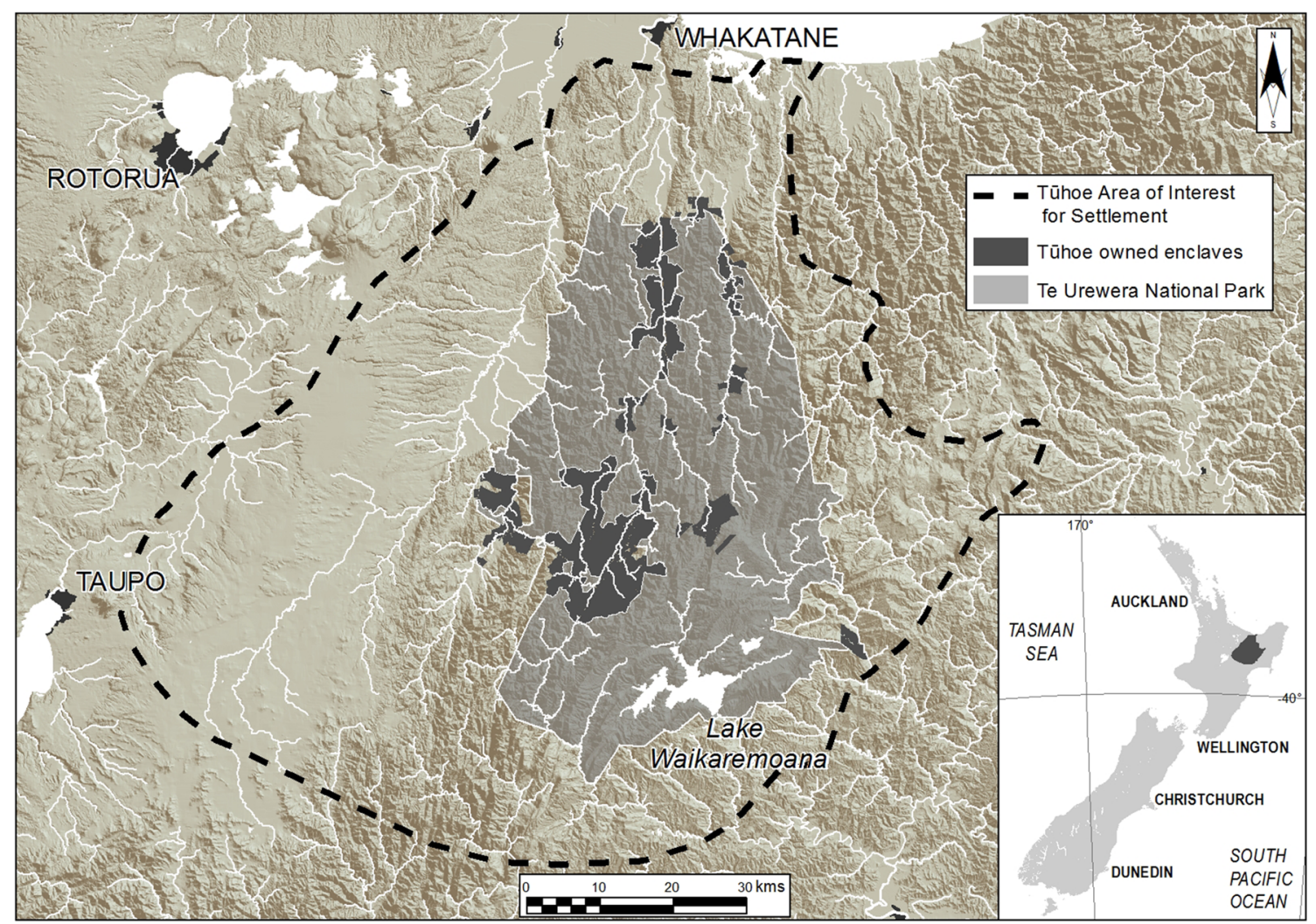

Fig. 1 Boundaries of Te Urewera National Park, private Tūhoe lands, and Tūhoe's Area of Interest relating to their Treaty of Waitangi settlement in the North Island, New Zealand

concept of relational values that emerged after this work, which relates to living a good life but derived from engagement between people, and reciprocity with the biophysical landscape (Chan et al. 2016; Klain et al. 2017). Other value types include instrumental (that justify and prioritize conservation action based on ecological benefits to people (Arias-Arévalo et al. 2017)) and intrinsic values ("value of ecosystems as ends to themselves and are often represented as moral duties" (Arias-Arévalo et al. 2018: 1)), both of which can overlap with relational values (Chan et al. 2018). For example, using nature for one's own benefit (i.e., instrumental) does not preclude feeling connected to nature (relational value), or believing that nature has value in itself (i.e., intrinsic).

\section{Methods}

\section{Background}

Te Urewera is one of the largest remaining areas of indigenous forest in the North Island, and the former Te Urewera NP was one of the larger parks in NZ (Fig. 1). The region contains a diverse range of vegetative types ranging from lowland, submontane, montane, subalpine forests, and lowland, subalpine mires (Department of Conservation 2003). It has also been a focus for tourism, recreation (e.g., hunting and hiking), and conservation efforts since the 1890s. Surrounding and embedded within Te Urewera are the remaining tracts of private Tūhoe lands and settlements.

\section{Participants and Procedure}

Prior to the interviews, potential groups of statutory and nonstatutory stakeholders ( $n=27$ groups) were identified by TKAT and the researchers. In order to explore and achieve a wider range of feedback, we also used a snowball sampling technique (Fossey et al. 2002), through which two additional stakeholder groups were identified. Stakeholder representatives were mailed an introductory letter by TKAT to request their participation in the study. An information sheet and list of potential interview questions were also provided. Following agreement with the stakeholders to be interviewed ( $n=18$ groups), TKAT then provided the list of representatives to contact to the researchers. Reasons that stakeholders declined to be interviewed included limited engagement with Te Urewera NP, or the small area that Te Urewera NP shared with their juristictional areas. The Department of Conservation, a government agency, declined to be interviewed on the premise that it would be inappropriate 
given the Crown was undertaking Treaty of Waitangi settlement negotiations with Tūhoe at the time.

Of the 18 stakeholder groups that participated, a total of 23 male and 4 female participants were interviewed. Groups were assigned as either statutory $(n=7)$ or non-statutory groups $(n=11)$. We defined statutory stakeholders as groups that engaged with Te Urewera NP (and Tūhoe) mostly through legislative and policy processes, while non-statutory stakeholders typically had a first-hand utilitarian (e.g., hunting, fishing, boating, hiking) and independent relationship with Te Urewera NP.

Of the 18 stakeholder groups interviewed, 14 were with single individuals from respective groups, while four comprised between two and seven individuals. Participants were advised that the results of the study and identification of the stakeholder groups involved would be made public, but were guaranteed confidentiality. Interviews were conducted faceto-face, with one exception of a phone interview with one group. Interviews were conducted between 28 February and 31 May 2012, and lasted between $22 \mathrm{~min}$ and $3 \mathrm{~h}$ and $20 \mathrm{~min}$. All interviews were conducted by one researcher (PL) and were audio recorded. They were conducted in a semistructured format with the interview protocol providing only a guide for discussions. Interview questions were jointly discussed with TKAT members to ensure relevant topics and concepts were addressed. Following the interviews, responses were summarised and sent to each of the stakeholder groups to check for accuracy. To aid interpretability, any pauses, stutters, and grammatical errors have been removed from participant quotes reported here.

\section{Coding and Analysis}

We conducted qualitative coding to analyse the data using nine primary values identified by Lyver et al. (2016) (Table 1). These values emerged as important to both Indigenous and non-indigenous stakeholders involved in the restoration of a coastal forest in northern NZ, and were chosen as our coding protocol (Saldana 2016) for their context relevance (i.e., interest group values in relation to an ecosystem). While the concept of relational values (see e.g., Chan et al. 2016, 2018) emerged after Lyver et al. (2016), it is noteworthy that many values in the protocol correspond with relational values. The nine values served as the primary codes. These codes comprised of secondary values (Corbin and Strauss 2008) identified inductively (i.e., derived from the data rather than from an existing set of values). For example, a primary value such as 'stewardship' (Lyver et al. 2016) contained the secondary value 'access.' Segments of interview text relating to the nine values were coded accordingly.

Values were assigned into two themes: (i) Current values conveyed the nature of the relationship that statutory and nonstatutory stakeholder groups had with Te Urewera NP at the time of the interviews; and (ii) Future values conveyed that each statutory and non-statutory stakeholder group desired to see realised should ownership or governance for Te Urewera NP be returned to Tūhoe.

The percentage $(\%)$ of stakeholder groups that referred to a value was calculated by assigning ' 1 ' to stakeholder groups who had spoken about the value at least once during the interview, and ' 0 ' (zero) to stakeholder groups who had not mentioned the value at all. The number of stakeholder groups where a value had been assigned at least once was summed and divided by the number of stakeholders in each grouping (i.e., statutory versus non-statutory). Percentages of stakeholders that were assigned a value to their interview narrative at least once were then compared between statutory and non-statutory stakeholder groupings.

In addition, The frequency that each value was assigned to narrative within each stakeholder interview was calculated and analysed using non-metric multidimensional scaling to visually determine differences between groups. Non-metric multidimensional scaling is a robust, unconstrained ordination technique commonly used in ecological studies (Kenkel and Orloci 1986). We also conducted a non-parametric multivariate analysis of variance (MANOVA) to test for differences in values between groups. The non-parametric MANOVA was performed using ANODIS from the 'vegan' library (Oksanen et al. 2019) in R 3.4.3 (R Core Team 2017), a function for the analysis and partitioning of distance matrices that is analogous to parametric MANOVA (Anderson 2001).

\section{Results}

\section{Current Values}

All stakeholder groups expressed stewardship as a key value at least once during their interviews (Fig. 2). It was suggested by some non-statutory stakeholders that everyone who uses $\mathrm{Te}$ Urewera NP takes a degree of 'ownership' in it. A number of non-statutory stakeholder groups recognised that the opportunity to achieve specific aims of their groups had relied heavily on their relationship with the (then) government department responsible for Te Urewera NP (e.g., the Department of Conservation; Supplementary material 1). Non-statutory stakeholders noted that their organisations received a fair chance of participating in decision-making under national park legislation.

Our alternate analysis using the frequency that values were assigned to narrative within interviews demonstrated that statutory stakeholder groups were more strongly associated with stewardship than non-statutory stakeholders, although the two Fish and Game authorities (a quasi-governmental group responsible for gamebird hunting and freshwater fishing management), were also aligned with 'personal use - consumptive' $\left(F_{1,16}=\right.$ 8.57, $p=0.001$; Fig. 3a). The Forest and Bird group (an 
Table 1 Nine core non-Indigenous stakeholder values relating to Te Urewera National Park

Value $\quad$ Value statements

1. Connection

2. Economic use

3. Intrinsic

4. Knowledge \& wisdom

5. Personal engagement

6. Personal use consumptive

7. Personal use non-consumptive
Refers to relationships, both among people (including building understanding, facilitating cross-cultural linkages and interactions, and connecting communities) and between people and place.

It is about being out in the natural world and seeing, hearing, smelling and feeling the diverse biodiversity of the area.

For example, hunting, fishing, and tramping provide opportunities to experience the challenges in a small-group environment (e.g., couple of friends). Experiences provide topics of conversation when people meet, which binds people together.

Experiences are integral to the lives of hunters, anglers and hikers which can define the individual and the group. 'It's what we do as New Zealanders.

It has become a generational thing - grandfathers and fathers have spent a lot of time up there and now children and grandchildren of members are also going up there. One thing in common is that people love the place [Te Urewera] and have a passion for it.

Differs from 'Personal Engagement' in that 'Connection' can occur among individuals who have met by chance, whereas 'Personal Engagement' relates to organised activities.

Having a little piece of paradise, feeling privileged to have access to, and enjoying the peace and tranquillity.

Wanting to leave a legacy for future generations.

Specifically addresses the commercial and business opportunities used to provide economic benefit for stakeholders.

The park provides employment and business and revenue opportunities for sectors of the community (e.g. professional fishing guides; possum harvesters; motor camp, water-taxi and helicopter services, park and conservation employees).

It supports New Zealand's exposure and standing on the world stage as a region of significant natural beauty, a travel destination, and New Zealand's capabilities to protect its wild places and biodiversity.

Concessions from guided freshwater angling and helicopter operations offer future opportunities for revenue production.

Reflects the value around species' right to exist within Te Urewera NP free from human-related interference or disturbance. The principle of National Parks ensures that this biological component is preserved.

Te Urewera forests represent historical New Zealand since forests have been destroyed elsewhere.

It has intrinsic value in that the forests, rivers, lakes, wetlands and the species that exist in these ecosystems have value simply by being there. It is knowing that the richness of our nature is not being lost.

Designation as a national park lifts the area's mana (i.e., prestige) and preserves the area's intrinsic value.

It is about remoteness, isolation (i.e., having the place to oneself), wildness and naturalness. Lake Waikaremoana being difficult to access ensures that it retains its intrinsic value. This value is the outcome of management (i.e., the park is being managed to this value) around the principles of the National Parks Act (For management see 'Stewardship').

Refers to the mutual concept of teaching (imparting knowledge to others) and learning (gaining knowledge), both from people and the environment.

The park [Te Urewera NP] provides opportunities that build: (1) life experiences; (2) an intergenerational experience and teaching of life skills, natural history and bush craft; and (3) identity that bonds individuals with predecessors, family, friends, youth, work colleagues, and community. Includes education and training.

Includes professional managers' knowledge around protecting New Zealand's biodiversity (e.g. Department of Conservation - DOC).

Reflects the valuable role of Te Urewera NP in providing opportunities for direct action and empowering people to make a difference.

Relates to being an active part of the formalised process of managing the park (e.g., restoration). It is about being part of club or association activities. Does not relate to decision-making around management (see 'Stewardship') or business or profit (See 'Economic use'). The park provides an opportunity to be involved in something bigger than yourself, giving a sense of ownership and belonging (e.g. voluntary labour towards conservation work, search and rescue, development and maintenance of infrastructure, financial donations).

It provides opportunities that build identity and bond individuals with predecessors, family, friends, youth, work colleagues, and community in organised activities.

Refers to the consumptive ways of using Te Urewera NP for the purpose of human benefit.

Such uses include, but are not limited to, food, medicine and recreation, such as hunting, fishing (fishing with lure and/or bait which includes catch and release due to the aspect of 'consumption' in catching fish, even if later released), and angling (fly fishing which includes catch and release). Commercial business-and-economic use was considered separately.

The park is a popular hunting and fishing location allowing individuals to supplement diet with 'wild foods' and also target deer herds of significance (Javan rusa, Rusa timorensis) and rainbow trout strains (Oncorhynchus mykiss - Ruakituri riverine strain).

Refers to the non-consumptive ways of using Te Urewera NP (e.g., for a wilderness experience, hiking, and bird watching).

A wilderness experience refers to being faced with a challenging, wild environment, where navigating the terrain offers the opportunity for one's individual skill set to be put to the test.

With half of New Zealand's population living north of Taupo, Te Urewera NP is the largest unbroken tract of native forest in the vicinity of this populace and therefore represents their main recreational opportunity to 'go bush'. 
Table 1 (continued)

\begin{tabular}{ll}
\hline Value & Value statements \\
\hline 8. Personal well-being & Te Urewera provides an experience of dense forest that cannot be gained anywhere else. \\
Refers to how Te Urewera NP affects people in terms of their physical and psychological health and well-being. Te \\
Urewera being a special place (i.e., with benefits for health and well-being). \\
The park offers an expanse of quiet, undisturbed place for many New Zealanders to escape the rigours and stress of \\
everyday work and home life - it has spiritual and healing value and restores 'frame of mind'. It is a place to de-stress. \\
The remote, natural quiet and serenity of Te Urewera NP are hugely important to personal experience. It is what people go \\
there for, and what draws them back time after time. \\
The park environment offers visitors opportunities to challenge their individual skill sets, use their judgement, \\
problem-solve, and fosters teamwork and comradeship (e.g., while moving across the landscape hiking, camping, \\
boating, hunting, and fishing), which has positive effects on their well-being. \\
Refers to concepts such as participating in the decision-making and management of Te Urewera NP with the goal of \\
looking after the resource for future generations. \\
Relates to the management of Te Urewera by governing bodies and clubs/associations, whose role may include ensuring \\
that: \\
- Rules and regulations are enforced \\
- The park retains its intrinsic value (i.e., does not get over-developed) \\
to have value as a bequest to future generations of New Zealanders \\
- Everyone has a fair chance of putting their perspectives and views out there where a decision-maker weighs those \\
interests up and decides a course of action based around principles of the National Parks Act \\
• Park users support these governing bodies groups because of shared values and because they feel a degree of ownership \\
towards the park. Working to maintain good working relationships with other stakeholders.
\end{tabular}

environmental preservationist non-government organisation) was most associated with 'intrinsic' value of Te Urewera NP (Fig. 3a).

'Connection' to Te Urewera NP was the second most common value expressed across both statutory and nonstatutory stakeholder groups, albeit to a lesser extent among statutory stakeholders (Fig. 2; Supplementary material 1). The importance of building or maintaining within-group relationships was especially evident among non-statutory stakeholder groups, who highlighted the satisfaction of sharing experiences in Te Urewera NP with others in their group. In many cases, this connection was inter-generational and childhood memories and camaraderie kept people coming back to the area.
Fig. 2 Percentage (\%) of statutory $(n=7)$ and non-statutory $(n=11)$ stakeholder groups that had: (i) current values assigned with regard to their relationship with Te Urewera National Park; and, (ii) future values that stakeholders wished to see achieved if the ownership or governance of Te Urewera National Park be returned to Tūhoe

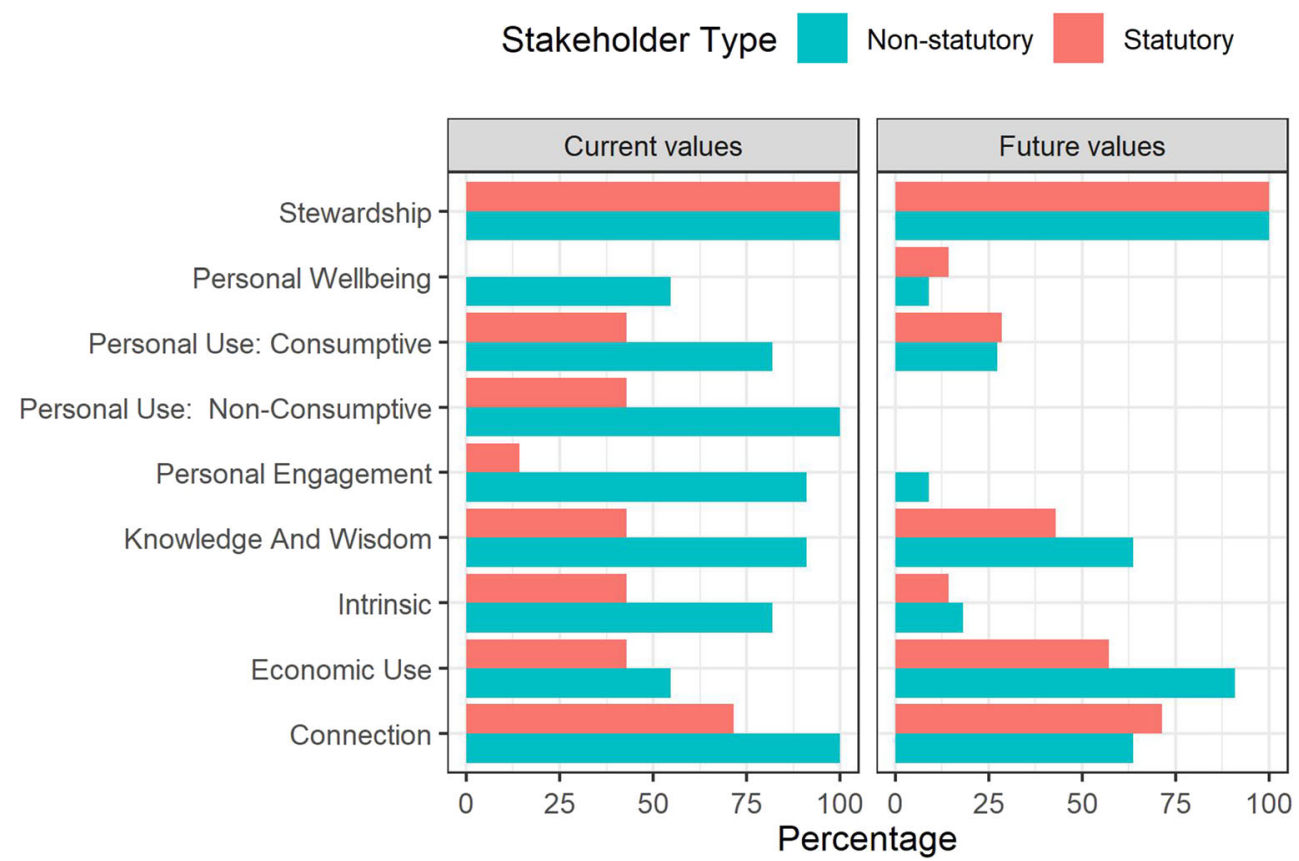


We've got club members and...I'm one of them, and [another family], they're there, my Dad and their Dad..., I've been going up the lake since I was about 10 and I'm 59 , so I've been going up there for 50 years. (Non-statutory group member)

A common goal of non-statutory stakeholders especially was the desire for Te Urewera NP to remain as a legacy for future generations, considering it a special place. In contrast, statutory stakeholder groups tended to hold a more distant, and procedural relation with Te Urewera $\mathrm{NP}$, given their function as administrators or managers, rather than users of the park.

While the statutory stakeholders also discussed 'stewardship' and 'connection' as their two most frequent values, the other seven primary values were mentioned in fewer than $50 \%$ of interviews (Fig. 2). In contrast, the non-statutory group members mentioned all values in more than $50 \%$ of the interviews. The largest differences in values between the two groups were in relation to 'personal engagement,' 'personal wellbeing,' 'personal use consumptive,' 'knowledge and wisdom,' and 'intrinsic' values (Fig. 2).

The high prevalence of non-statutory stakeholders who emphasized 'personal use (non-consumptive)' in their interviews also reflected how much they valued Te Urewera NP for the wilderness experience it provides, its isolation, and the challenge of a wild environment, and partaking in activities such as bird watching and hiking. These stakeholders particularly enjoyed staying in public huts or club lodges within Te Urewera NP (Fig. 2; Supplementary material 1).

Values regarding knowledge and wisdom were connected to the provision of opportunities to educate youth (e.g., native vegetation identification) and adults (e.g., bush craft, hunting, fishing, or the history of Te Urewera NP) within a natural forest environment (Fig. 2 ; Supplementary material 1 ). The creation of opportunities to transfer knowledge and experiences between stakeholder groups and with Tūhoe were also identified as important to non-statutory stakeholders, most of whom also valued the opportunity to actively engage in projects and activities around Te Urewera NP (i.e., 'personal engagement'; Fig. 2; Supplementary material 1 ), with some having volunteered over many years. A passion for Te Urewera NP and a willingness for their contributions to benefit the community were evident for some stakeholders (Supplementary material 1).

\section{Future Values}

A desire to build stronger formal relationships (e.g., fostering good relationships with Tūhoe and other stakeholders) was highlighted by many of the stakeholders as important for the stewardship of Te Urewera (Fig. 2; Supplementary material 2). Members of both stakeholder groups acknowledged that there had been little formal engagement with Tūhoe in the past. In most cases, it was perceived that such formal contact was not needed for organisations to function in Te Urewera NP. While a large proportion of stakeholders supported the ownership and/or governance of Te Urewera NP being returned to Tūhoe through their settlement (Supplementary material 2), all stakeholder groups expressed a desire to share a stewardship role and be consulted in its future management (Supplementary material 2). Nevertheless, there was an expression of caution as to how quickly Tūhoe should be making any changes within Te Urewera NP, with a preference for a process of gradual change:

I think, a process that is evolutionary rather than revolutionary will actually carry the day (Statutory group member)

Stakeholders wished for public interest to remain at the forefront of Te Urewera NP management, and that the area be managed professionally, according to the principles of the National Parks Act (1980). It was perceived that enshrining current national park legislation and regulations in any future stewardship arrangement would be critical for protecting $\mathrm{Te}$ Urewera's biodiversity:

They [Tūhoe] should manage the park with all due diligence to the conservation values of the park and the... Acts and regulations as set down under the Act .... protected wildlife, the ongoing feral animal control. (Non-statutory group member).

One stakeholder group particularly emphasized the importance of keeping Te Urewera NP classified as a national park due to the high status of national parks, in order to attract tourists and provide a source of revenue for Tūhoe. The provision of funding to Tūhoe by the Crown was also considered to be an important secondary value to future stewardship of Te Urewera (i.e., to look after Te Urewera and its biodiversity; Supplementary material 2). Even so, the financial autonomy of Tūhoe (i.e., self-determination) was also seen by both stakeholder groups as an important value for the future. In particular, the creation of local business opportunities that employed local Tūhoe people was reported as important for the tribe by some stakeholders, particularly by non-statutory stakeholder groups. Guided activities (e.g., hiking, fishing, or hunting) and high-end tourism (e.g., luxury accommodation; cultural experiences) opportunities that utilised the natural and cultural features of Te Urewera NP were suggested as possible avenues to explore. 


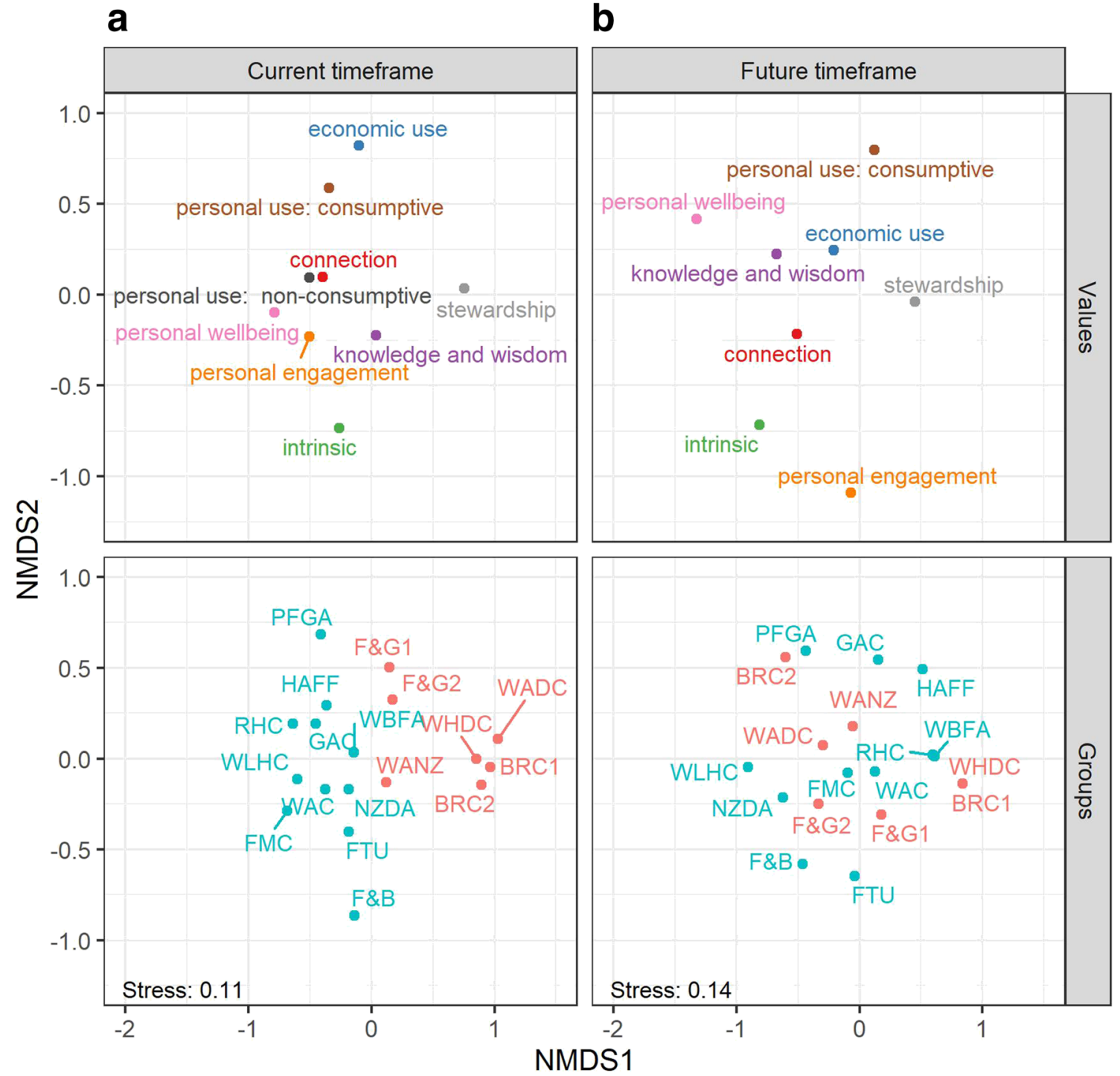

\section{Stakeholder Type}

Fig. 3 Differences in values that statutory $(n=7)$ and non-statutory $(n=$ 11) stakeholder group currently have with Te Urewera National Park (a), and those future values they wished to see achieved if the ownership or governance of Te Urewera National Park was returned to Tūhoe (b). Plots represent the results of non-metric multidimensional scaling analyses (NMDS), with the spread of current and future values shown on the top row; and statutory and non-statutory stakeholder groups on the bottom row. Values codes are: economic use (orange); personal use: consumptive (dark blue); personal use: non-consumptive (light blue); connection (red); stewardship (pink); personal wellbeing (pink); knowledge and wisdom (green); personal engagement (aqua blue); and intrinsic (light green).

But I think, if I had one thing to stress, it would certainly be, get something out of it for your people (Non-statutory group member)

Concerns about over-commercialized of Te Urewera NP that would spoil its current natural character were

\section{Non-statutory - Statutory}

Stakeholder codes are: Forest and Bird (F\&B); Friends of Te Urewera $(F T U)$; Gisborne Angling Club (GAC); Professional Fishing Guides Association ( $P F G A)$; Federated Mountain Club (FMC); Te Urewera Raukumara Hunting Club (RHC); Waikaremoana Boating and Fishing Association (WBFA); Wairoa Angling Club (WAC); Whakatane Lions Hut Committee (WLHC); New Zealand Deerstalkers Association (NZDA); Hunting and Fishing Forum $(H A F F)$; Bay of Plenty Regional Council 1 (BRC1); Bay of Plenty Regional Council 2 (BRC2); Fish and Game $(F \& G 1)$; Fish and Game Eastern $(F \& G 2)$; Wairoa District Council $(W A D C)$; Walking Access NZ (WANZ); and Whakatane District Council $(W H D C)$

expressed by some stakeholder groups. Many nonstatutory stakeholders felt that the current level of development was appropriate, and that increased commercialisation would threaten biodiversity and spoil the ambience and natural features of Te Urewera. Fears around the use of certain pest control methods (i.e., 
aerial application of toxins primarily to control invasive Australian brushtail possum, Trichosurus vulpecula, populations) and how this might affect economic opportunities (e.g., guided hunting) were raised.

They [Tūhoe] want to give it absolutely 100 percent authentic experience up there and they don't want people then to come down tomorrow and get some downgraded version of it. They want us to maintain a very high standard around Māori tourism and we agree with that (Statutory group member).

Values relating to the return of Te Urewera NP to Tūhoe encompassed keeping fair, free, and secure access to the area for all members of the public (Supplementary material 2). Overall, non-statutory groups in particular did not wish to see changes in terms of their connection to and existing activities in Te Urewera NP (Fig. 2; Supplementary material 2). The possible restriction of public access to the park was worrisome for some stakeholders. For example, those groups who valued staying in affiliated club lodges were anxious about losing access to them. Moreover, there were concerns that some members of the public, such as those with limited mobility, might lose their connection to the area if access was restricted in some way. Also, the 'exclusive capture' of fisheries (i.e., a practice where some private landowners bordering lakes, rivers, and streams restricted access to paying clients) was identified as a possible issue that could affect public access. Therefore, public support for the national park being returned to Tūhoe was seen by stakeholders as contingent upon public access being maintained. The allocation of public funding for Tūhoe to manage Te Urewera NP was suggested as a mechanism to maintain support within the tribe for public access to the area.

Both statutory and non-statutory stakeholder groups emphasized the value they placed on knowledge generation and transfer as part of their relationship with Te Urewera (Fig. 2; Supplementary material 2). Non-statutory stakeholders also emphasized Tūhoe's traditional knowledge and existing capacity around that knowledge system, which could be used to revive customary practices (e.g., customary bird harvest) or contribute to economic development opportunities such as tourism. It was suggested by stakeholders that growing capacity within Tūhoe people would be fundamental for allowing them to take full advantage of economic ventures within $\mathrm{Te}$ Urewera NP, and opportunities for training and experience would be critical to that growth. Support for growing Tūhoe's capability was seen by both stakeholder groups as important (Fig. 2; Supplementary material 2). Statutory stakeholders, in particular, were in a position to offer information and advice that they thought would be of benefit to the tribe.
So the aim was to actually try and grow their [Tūhoe's] own capacity and capability around doing things which they saw as being done by others within their area. So we flicked the switch on that and flipped it around and said, right, we'll train you up (Statutory group member).

In discourse about future governance, non-statutory stakeholders saw the need to become more directly involved in the stewardship of Te Urewera NP as much as the statutory stakeholders (Figs. 2 and 3b). This was evident in the intermingled alignment of both statutory and non-statutory stakeholder groups around values (e.g., stewardship) that they wished to see achieved if the ownership or governance be returned to Tūhoe $\left(F_{1,16}=1.06, p=0.338\right.$; Fig. $\left.3 \mathrm{~b}\right)$.

\section{Discussion}

\section{The Importance of Identity and Connection to Place}

The mountain ranges of Te Urewera NP, being the largest remaining expanse of forest in the North Island of NZ, combined with the cultural heritage of Tūhoe settlement, hold a unique position in the psyche of New Zealanders. Indeed, many stakeholders spoke of Te Urewera NP as a "special place". Te Urewera NP provided stakeholders with an extensive, quiet, and undisturbed place that delivers a high-quality experience. Engagement in intergenerational activities within the park (e.g., camping, fishing, boating, hiking, hunting, and inter-generational knowledge transfer) contributed to an identity for individuals and families, and facilitated bonding and ties among families, friends, and community. Forest users within developed nations often express a strong connection to the people they share time with in the forest environment (i.e., friends, family, fellow stakeholders), as well as to the place itself (MEA 2005; McNeill 2016). By developing a shared history and experience with the same place, the feeling of being part of a community with a collective identity and ownership was reinforced (Horwitz et al. 2001; Cheng et al. 2003). In this study, non-statutory stakeholders had contributed significant personal time, finances, and logistical resources to the development and maintenance of the services and infrastructure in Te Urewera NP as a consequence of their feeling of 'attachment to place' (Stedman 2002; Scannell and Gifford 2010; Lewicka 2011). It also gave participants a perspective of bequeathing their interest in the park to their children, grandchildren, and future generations.

A sense of connection to place and common identity are key relational values that drive relationships between peopleto-people and people-to-nature (Chan et al. 2018). These values can reaffirm social relationships between people and place in a way that facilitates mutual respect and kinship (Stewart et al. 2004; Leigh 2005; MEA 2005; Gould et al. 
2015). While an instrumental perspective may focus on using nature for one's own benefit, relational values provide a sense of common purpose around giving back to nature, which also promotes a greater diversity of perspectives, trust-building, reciprocity, and duty of care (Klain et al. 2017; Chan et al. 2018). Developing a sense of common identity or connection can be heavily influenced by instrumental or intrinsic values at the outset of an individual's engagement with a place; however, over time these values may achieve greater overlap with, or even transformation into, relational values within the individual and collectively. These values can be also used to enable cross-cultural contact and collaboration through the identification of common ground between interest groups (Gould et al. 2019). Non-statutory stakeholders in this study had long relationships with Te Urewera NP, which was manifested through extensive overlap between instrumental (e.g., personal use - consumptive) and relational (e.g., connection to place) values. We suggest that the expression of values from a perspective of what contributes to a good, meaningful life (Chan et al. 2016; van den Born et al. 2018) facilitated stakeholders' consideration and acceptance of an alternate governance system for Te Urewera NP centred on Indigenous people. Reflecting on their own perspective of living a good life (through connection to people and place) allowed stakeholders to consider Tūhoe governance as compatible with those values. We also postulate that an emphasis on relational values will facilitate greater cross-cultural linkages and empathy, and improve interactions allowing people to share their knowledge, break down cultural barriers and stereotypes, and improve governance (Tengö et al. 2014).

\section{Engaging Governance and Stewardship Systems that Support Conservation and Community Wellbeing}

Stakeholders expressed a sense of stewardship obligation for Te Urewera NP, especially statutory stakeholders (Fig. 3a). For non-statutory stakeholders who had been involved with Te Urewera NP since its inception, a sense of 'ownership' came from their personal connection, interaction, care, and passion for the area (Fig. 2). One non-statutory stakeholder group referred to themselves as a "watch-dog for Te Urewera NP," keeping a careful eye on how the park was being managed by the Department of Conservation, and how it was being used and treated by public visitors. There was a personal need to make a difference, to protect the landscape and its biodiversity, but also make it a place to enjoy, to build links between community and environment. This form of interplay between individual agency (power to act) and collective identity is recognised as fundamental for broader environmental care (Agrawal 2005; Clayton and Myers 2009; Phipps et al. 2011).

Competing values, uses of place, and aspirations can create significant challenges for joint governance or management arrangements that involve a complex array of actors within communities, government agencies, and industry (Carlsson and Berkes 2005; Nursey-Brayand Rist 2009). While stakeholders acknowledged that it was unlikely that Tūhoe's management would detrimentally impact Te Urewera NP, it was unclear how stakeholders would respond to possible changes in key areas that Tūhoe might implement (e.g., developing bylaws, activity and livelihood approvals, approving customary take requests, economic development initiatives; Te Urewera Board 2017). At the time of the study and settlement, Tūhoe were not in a position to articulate what these activities and changes might be, and many are currently still under consideration. However, it was likely that stakeholders would accept some level of change in the interest of preserving the current suite of benefits (e.g., access and connection) they enjoyed within Te Urewera NP. In this regard, governance that established a pluralistic stewardship system that engaged deliberative processes to link a diverse network of partners (e.g. tribal communities, government, nongovernment organisations) and nested institutional frameworks would be aspirational (Berkes 2007). Specifically, deliberative processes should be used to manage occasions where objectives such as those found within different conservation and development agendas pull in different directions (Brechin et al. 2003). In such a stewardship system, functions, inter-generational planning, entitlements, and responsibilities for conservation and development goals would be defined, negotiated, and agreed among the partners (Gavin et al. 2015).

Both statutory and non-statutory stakeholder groups expressed a desire for both conservation and development outcomes to be achieved in Te Urewera NP. The success of such initiatives within protected areas globally is, however, widely contested (see e.g., Wilshusen et al. 2002; Adams et al. 2004; Roe 2008; Blom et al. 2010; Zeller et al. 2017; Engen et al. 2019). Conclusions from studies are reported to be largely context-dependent, although recent findings identify that remaining areas of high biodiversity are commonly found on the lands of Indigenous peoples (IPBES 2019). In these situations, humans are often an integral part of the ecosystem and commercial development is minimal. Therefore, finding a balance between protecting biodiversity, maintaining features of naturalness, and ensuring a threshold of sustainability, while enhancing cultural, recreational, and economic activity presents a significant challenge (Drumm 2008). Visitors can preferentially choose to visit national parks because of the elevated aesthetic or biodiversity status attributed to those sites (e.g., Yellowstone NP, USA). A change from a national park to another protected area classification could potentially downgrade tourism activity and reduce opportunities for the community to obtain revenue from the area. However, new opportunities are emerging through promotion of regions as 'biocultural landscapes' (Maffi and Woodley 2010) where a diversity of cultural, social, 
environmental, and development objectives and a diversity of human-ecosystem interactions are managed. In Australia's Northern Territory, the return of Nitmiluk NP to Jawoyn Aboriginal ownership provided a preferential right to establish commercial enterprises inside the park, as well as securing service contracts to conduct park management tasks (Bauman and Smyth 2007). Jawoyn values of cooperative action have facilitated economic growth opportunities, not only for the Jawoyn people, but also for the non-aboriginal community in Katherine and Northern Territory (Bauman 2007). It was recognised that the new arrangement is "an ongoing process and requires changes of mindset according to current priorities in the Park and the existing capacity of all involved" (Bauman and Smyth 2007: 13-14).

\section{No One Owns Te Urewera: Social Equity Within a Juristic Personhood Framework}

Under the Convention on Biological Diversity (2010) Aichi Target 11 "protected areas should be established and managed in close collaboration with, and through equitable processes that recognize and respect the rights of indigenous and local communities, and vulnerable populations." It emphasizes that "these communities should be fully engaged in governing and managing protected areas according to their rights, knowledge, capacities and institutions, should equitably share in the benefits arising from protected areas and should not bear inequitable costs." However, in a recent global survey of protected area staff and community representatives over $50 \%$ of respondents saw significant challenges to achieving equitably managed protected areas with IPLC (Zafra-Calvo et al. 2019). This study and others (Nepal 2002; McDermott et al. 2012; Lyver et al. 2014; Sikor et al. 2014; Dawson et al. 2017) suggest that stronger mechanisms within protected area governance and management are needed to balance three key dimensions of equity for IPLC: (i) Recognition - acknowledging and respecting rights, identities, knowledge systems, values, and institutions of different stakeholders; (ii) Procedure - diverse participation of stakeholders in decision making, transparency, accountability, and processes for dispute resolution; and, (iii) Distribution - dispersal of benefits (e.g., socioeconomic) across stakeholders, and mitigating burdens (e.g., potential loss of food security) experienced by some stakeholders (Franks et al. 2018). Finding alternate approaches that go beyond conventional Western conservation frameworks to deliver equity across a range of stakeholders is therefore fundamental (see also Butchart et al. 2015).

The current protected area system in NZ provides largely for a Euro-centric connection with the environment (e.g., protection of intrinsic biodiversity values, conservation, tourism, fishing and hunting of introduced species), but limits the relationship Māori aspire to have with their lands (Coombes and Hill 2005; Ruru 2004, 2008). However, the recent delisting of Te Urewera NP and its reclassification as "a legal entity" with "all the rights, powers, duties, and liabilities of a legal person" (section 11, Te Urewera Act 2014, New Zealand Government 2014) was an attempt to address equity for Te Urewera and Tūhoe through NZ's Treaty of Waitangi settlement process. The reclassification of Te Urewera NP as a legal juristic personhood provided the government with a politically acceptable solution to circumvent the Tūhoe proposal for outright ownership of the park (Ruru et al. 2017). It provided Tūhoe with a framework to redress Te Urewera identity, shift the focus to the management of people for the benefit of the land, and deliver equitable outcomes for its people and also the wider public (Te Urewera Board 2017). Moreover, through the newly established Te Urewera Board, a joint governance board comprised of Tūhoe and Crown membership, Tūhoe gained the opportunity "to act on behalf of, and in the name of, Te Urewera" (section 11, Te Urewera Act 2014), and "to provide governance for Te Urewera" (New Zealand Government 2014, Schedule 6, Part 2, clauses 17a and 17b). And it is through the functions of the Te Urewera Board that Tūhoe wished to "deliberately reset the human relationship and behaviour towards nature" (Te Urewera Board 2017).

While the concept of juristic personhood is not new, its capacity as a framework to deliver equitable governance and management for protected areas remains novel within the modern conservation context (Stone 1972; Sanders 2017; Studley and Bleisch 2018). Over the last two decades, however, an increasing number of bio-physical entities in different countries have been accorded legal rights (e.g., PachamamaEarth Goddess in Ecuador) and juristic personhood (e.g., Te Awa Tupua-Whanganui River and Mount Taranaki in NZ; Ganga and Yamuna Rivers including their 115 tributaries in India) giving those entities the protections, obligations and rights to exist, persist, maintain, and regenerate vital cycles, structure, functions, and processes in evolution as a legal subject (The New Zealand Parliamentary Counsel Office 2016; Safi 2017; Gordon 2018; Studley and Bleisch 2018). For IPLC, the juristic personhood framework resonates more closely with their worldviews and the reciprocating familial relationships that they hold with other-than-human entities, than other protected area classifications. For Tūhoe, recognising Te Urewera as its own legal person links directly with their concept of whakapapa, which is the sequential system that portrays the identities and interconnectedness between all elements of the living and non-living realms (Timoti et al. 2017). It provides the cultural context for Tūhoe, through the Te Urewera Board, to legally exercise legal guardianship and represent the rights of Te Urewera, and to also open up conversations with other interest groups through an interface that reflects Tūhoetanga (Tūhoe principles and values). Moreover, it allows for the reconciling 
of both key cultural (Te Urewera principles: Papatūānuku landscape; mauri - life; tapu - resilience; āhua - character; tātai - heritage; and whānau, manuhiri and tanata whenuadiscipline and wellbeing of the collective; see Te Kawa o Te Urewera - Te Urewera Board 2017) and environmental governance principles (e.g. legitimacy, transparency, accountability, inclusiveness, fairness, connectivity, and resilience; Lockwood 2010) in the 'management of people' for the benefit of Te Urewera.

Te Urewera provides a unique scenario in that Tūhoe have tasked themselves with accounting for the values of nonTuhoe stakeholders, while they are still addressing the values and inequity of colonialization from the past 175 years for their own people. This approach represents the ethos embraced within Te Kawa o Te Urewera that Te Urewera "is about the management of people for the benefit of the land it is not about land management" (T. Kruger, Te Kawa o Te Urewera - Te Urewera Board 2017: 2). For Tūhoe, creating conditions for 'inclusiveness' in management in a way that accommodates many of the stakeholder aspirational values (Fig. 3) was a key component of a new governance framework. Inclusiveness for stakeholders encompassed meaningful participation in management with an opportunity to influence decision-making, processes, and action (e.g., stewardship). Stakeholder groups, such as Friends of Te Urewera, can be invited by the Te Urewera Board to assist with activities such as biodiversity and pest management, service delivery (e.g., hut and hiking track maintenance; boating infrastructure, such as ramps), and the creation of economic development opportunities (e.g., eco-tourism). It provides opportunities for Te Urewera stakeholders to continue their stewardship role and contribute to supporting the integrity of places (e.g., through voluntary labour and logistics) to which they may hold a strong relational attachment, and which can continue to shape their identity (Hernández et al. 2007; Scannell and Gifford 2010; Bennett et al. 2018). Inclusive governance is beneficial because it can better integrate a range of interests and values, provide conditions to engage diverse knowledge systems, improve learning, build trust and legitimacy, enhance ownership and commitment to solutions, and increase capacity to mediate competing interests and conflict (Lockwood 2010; Young et al. 2013). An inclusive process also emphasises the need to clarify the goals and role of all stakeholders involved. This can lead to a more resilient governance system that is better positioned to assimilate new information and adapt decision-making and actions (Decker et al. 2016). Increased stakeholder involvement can also build capacity in systems to cope with change and uncertainty, reduce negative attitudes towards management initiatives, and buffer against unanticipated social and biological feedbacks (Sterling et al. 2017; Mannetti et al. 2019). It is through these processes of inclusivity that Tühoe perceive people and groups giving back to Te Urewera.

\section{Conclusion}

Despite differences in how Indigenous and nonindigenous people might express their strongest values with regard to protected areas, non-indigenous stakeholder groups share common relational values with IPLC with regard to stewardship and connection to people and place. Juristic personhood is potentially a powerful governance and management framework to integrate values and needs of both Indigenous peoples and non-indigenous stakeholders. The designation has the potential to facilitate both community wellbeing and ecological protection, since balance and reciprocity (interconnectedness of humans and nature) and ecological integrity are a fundamental part of IPLC worldview. Legal personhood can also recognise and protect the rights and cultural integrity of IPLC through self-determination, while giving nonindigenous stakeholders some reassurance that the area will be protected for current and future generations. The designation may fulfil the paramount goal of protecting nature, while reconnecting all people to nature. Protected areas under legal entity are also ideal mechanisms to disentangle issues of IPLC rights and power and to facilitate inter-cultural linkages and exchange.

Acknowledgments We thank members of Te Kotahi a Tūhoe for their directorship and support. A special thanks to members of the stakeholder groups (Gisborne Angling Club, Fish and Game-National, Fish and Game-Eastern, Federated Mountain Club, Fish and Hunt Forum, Forest and Bird, Friends of Te Urewera, New Zealand Deerstalkers Association, New Zealand Professional Fishing Guides Association, New Zealand Walking Access Commission, Te Urewera-Raukumara Hunting Club, Waikaremoana Boating and Fishing Club, Wairoa Anglers Club, and Whakatane Lions Hut Committee) and representatives of territorial and local authorities (Bay of Plenty Regional Council, Wairoa District Council, and Whakatane District Council) for their participation in our interviews. Our project was funded by Te Kotahi a Tūhoe and the Strategic Science Investment Funding (SSIF) for Crown Research Institutes from the Ministry of Business, Innovation, and Employment's Science and Innovation Group.

Authors' Contributions KL, TK, RA, and PL conceived the research; PL conducted the interviews; CB, SM, AW and PL developed the analyses; $\mathrm{CB}$ and $\mathrm{AW}$ analysed the data; CB, SM, KL, TK, RA, AW and PL wrote and edited the manuscript.

\section{Compliance with Ethical Standards}

All participants received an introductory letter from Te Kotahi a Tūhoe to request their involvement in the research. A research information sheet and list of questions were also provided by researchers ahead of interviews. Transcripts of interviews were provided to participants for their review. Interviews were conducted in accordance with Te Kotahi a Tūhoe - Manaaki Whenua Landcare Research Cultural Ethic Agreement.

Conflict of Interest The authors KL and TK were members of Te Kotahi a Tūhoe at the time that interviews were conducted. 
Open Access This article is licensed under a Creative Commons Attribution 4.0 International License, which permits use, sharing, adaptation, distribution and reproduction in any medium or format, as long as you give appropriate credit to the original author(s) and the source, provide a link to the Creative Commons licence, and indicate if changes were made. The images or other third party material in this article are included in the article's Creative Commons licence, unless indicated otherwise in a credit line to the material. If material is not included in the article's Creative Commons licence and your intended use is not permitted by statutory regulation or exceeds the permitted use, you will need to obtain permission directly from the copyright holder. To view a copy of this licence, visit http://creativecommons.org/licenses/by/4.0/.

\section{References}

Adams, W. M., Aveling, R., Brockington, D., et al (2004). Biodiversity conservation and the eradication of poverty. Science 306: 1146 -1149 .

Agrawal, A. (2005). Environmentality. Technologies of government and the making of subjects. Durham and London, Duke University Press.

Anderson, M. J. (2001). A new method for non-parametric multivariate analysis of variance. Austral Ecology 26: 32-46.

Arias-Arévalo, P., Martín-López, B., Gómez-Baggethun, E., (2017). Exploring intrinsic, instrumental, and relational values for sustainable management of social-ecological systems. Ecology and Society 22(4), 43

Arias-Arévalo, P., Gómez-Baggethun, E., Martín-López, B., et al (2018). Widening the evaluative space for ecosystem services: a taxonomy of plural values and valuation methods. Environmental Values 27: 29-53.

Aswani, S. and Weiant, P. (2004). Scientific evaluation in women's participatory management: monitoring marine invertebrate refugia in the Solomon Islands. Human Organisation 63: 301-319.

Barnes, M.D., Craigie, I.D., Harrison, L.B., et al (2016). Wildlife population trends in protected areas predicted by national socio-economic metrics and body size. Nature Communications 7: 12747.

Bauman, T. (2007). Nitmiluk National Park: joint management as process and balancing interests. In: Indigenous partnerships in protected area management in Australia: three case studies (eds.), Bauman T. and D. Smyth). Australian Institute of Aboriginal and Torres Strait Islander Studies, Canberra, Australia, pp. 17-70.

Bauman, T., and Symth, D. (2007). Outcomes of three case studies in Indigenous Partnerships in Protected Area management. Policy briefing paper for the Australian collaboration. Australian Institute of Aboriginal and Torres Strait Islander Studies and The Australian Collaboration, Canberra, Australia, 32p.

Bennett, N. J., Whitty, T. S., Finkbeiner, E., et al (2018). Environmental stewardship: a conceptual review and analytical framework. Environmental Management 61: 597-614.

Berkes, F. (2007). Community-based conservation in a globalized world. PNAS 104, 15188-1519.

Binney, J. (2009). Encircled lands: Te Urewera 1820-1921. Bridget Williams Books, Wellington, NZ, $670 \mathrm{p}$.

Blom, B., Sunderland, T. and Murdiyarso, D., (2010). Getting REDD to work locally: lessons learned from integrated conservation and development projects. Environmental Science and Policy 13: 164172.

Borrini-Feyerabend, G., Kothari, A. and Oviedo, G. (2004). Indigenous and local communities and protected areas towards equity and enhanced conservation guidance on policy and practice for comanaged protected areas and community conserved areas. World
Commission on Protected Areas (WCPA), Best Practice Protected Area Guidelines, Series No. 11, IUCN, Gland, Switzerland, 113 p.

Brechin, S. R, Wilshusen, P. R, Fortwangler, C. L, et al. (eds.) (2003). Contested Nature. State University of New York Press, Albany, NY, USA.

Butchart, S. H. M., Clarke, M., Smith, R. J., Sykes, R. E., et al. (2015). Shortfalls and solutions for meeting national and global conservation area targets. Conservation Letters 8: 329-337.

Parks Canada (2010). Tongait KakKasuangita SilakKijapvinga - Torngat Mountains National Park Canada Management Plan, Parks Canada, Ottawa, Canada, $60 \mathrm{p}$.

Carlsson, L. and Berkes, F. (2005). Co-management: concepts and methodological implications. Journal of Environmental Management 75: 65-76.

Chan, K. M. A., Balvanera, P., Benessaiah, K., et al (2016). Opinion: Why protect nature? Rethinking values and the environment. PNAS 113(6): 1462-1465.

Chan, K. M. A., Gould R. K. and Pascual, U. (2018). Editorial overview: Relational values: what are they, and what's the fuss about? Current Opinion in Environmental Sustainability 35: A1-A7.

Chape, S., Spalding, M. Taylor, A. et al (2008). History, definitions, value and global perspective. In: Chape, S., Spalding, M., Jenkins, M. (eds.), The world's protected areas - status, values and prospect in the 21 st century. University of California Press, Los Angeles, California, USA, pp. 1-35.

Cheng, A. S., Kruger, L. E., and Daniels, S. E. (2003). "Place" as an integrating concept in natural resource politics: propositions for a social science research agenda. Society and Natural Resources 16 : 87-104.

Clayton, S., and Myers, G. eds (2009). Conservation psychology. Understanding and promoting human care for nature. WileyBlackwell, Oxford, UK.

Cleghorn, H. (1861). The forests and gardens of South India. W.H. Allen, London, United Kingdom.

Convention on Biological Diversity (2010). Target 11 - Technical rationale extended (provided in document COP/10/INF/12/Rev.1). https://www.cbd.int/sp/targets/rationale/target-11/. Accessed 30 May 2020

Coombes, B. L. and Hill, S. (2005). "Na whenua, na Tūhoe. Ko D.o.C. te partner"-Prospects for Comanagement of Te Urewera National Park. Society and Natural Resources 18(2): 135-152.

Corbin, J. M. and Strauss, A. L. (2008). Basics of qualitative research: techniques and procedures for developing grounded theory (3rd ed.). Sage Publications, Inc., Los Angeles, California, USA.

Craigie, I. D., Baillie, J. E. M., Blamford, A., et al (2010). Large mammal population declines in Africa's protected areas. Biological Conservation 143: 2221-2228.

Dasmann, R. F. (1984). The relationship between protected areas and indigenous peoples. In: McNeely, J.A., Miller, K.R. (eds.), National parks, conservation, and development: the role of protected areas in sustaining society. Smithsonian Institution Press, Washington (DC), USA, pp. 667-671.

Dawson, N., Martin, A., and Danielsen, F. (2017.) Assessing equity in protected area governance: approaches to promote just and effective conservation. Conservation Letters, 11: 1-8, e12388.

Decker, D., Smith, C., Forstchen, A., Hare, D., et al (2016). Governance principles for wildlife conservation in the 21 st Century. Conservation Letters 9: 290-295.

Department of Conservation (2003). Te Urewera National Park Plan. Department of Conservation, Wellington, New Zealand.

Dovers, S., Feary, S., Martin, A., McMillan, L., Morgan, D. and Tollefson, M. (2015) 'Engagement and participation in protected area management: who, why, how and when?', in G. L. Worboys, M. Lockwood, A. Kothari, S. Feary and I. Pulsford (eds) Protected Area Governance and Management, pp. 413-440, ANU Press, Canberra, Australia. 
Drumm, A. (2008). The threshold of sustainability for protected areas. Bioscience 58: 782-783.

Engen, S., Fauchald, P., and Hausner, V. (2019). Stakeholders' perceptions of protected area management following a nationwide community-based conservation reform. PLoS ONE 14(4): e0215437.

Fiallo, E. and Jacobson, S. (1995). Local communities and protected areas: attitudes of rural residents towards conservation and Machalilla National Park, Ecuador. Environmental Conservation 22: $241-250$.

Fossey, E., Harvey, C., McDermott, F., and Davidson, L. (2002). Understanding and evaluating qualitative research. Australian and New Zealand Journal of Psychology 36(6): 717-732.

Franks, P., Booker, F., and Roe, D. (2018) Understanding and assessing equity in protected area conservation: a matter of governance, rights, social impacts and human wellbeing. IIED Issue Paper. IIED, London, $38 \mathrm{p}$.

Gavin, M. C., McCarter, J., Mead, A., Berkes, F. et al. (2015). Defining biocultural approaches to conservation. Trends in Ecology and Evolution 30: 140-145.

Gordon, G.J. (2018). Environmental Personhood. Columbia Journal of Environmental Law 43: 49-91.

Gould, R. K., Klain, S. C., Ardoin, N. M., Satterfield, T., et al (2015). A protocol for eliciting nonmaterial values through a cultural ecosystem services frame: analyzing cultural ecosystem services. Conservation Biology, 29(2): 575-586.

Gould, R. K., Pai, M., Muraca, B., and Chan, K. M. A. (2019). He 'ike 'ana ia i ka pono (it is a recognizing of the right thing): how one indigenous worldview informs relational values and social values. Sustainability Science 14: 1213-1232.

Graham, J., Amos, B., and Plumptre, T. (2003). Governance principles for protected areas in the 21 st century. Institute on Governance, Ottawa, Ontario, Canada.

Hernández, B., Hidalgo, M. C., Salazar-Laplace, M. E., and Hess, S. (2007). Place attachment and place identity in natives and non-natives. Journal of Environmental Psychology 27, 310-319.

Holmes, G. (2013). Exploring the relationship between local support and the success of protected areas. Conservation and Society 11: 72-82.

Horwitz, P., Lindsay, M., and O'Connor, M. (2001). Biodiversity, endemism, sense of place, and public health: inter-relationships for Australian inland aquatic systems. Ecosystem Health 7: 253-265.

Johnson, C. N., Balmford, A., Brook, B. W., Buettel, J. C., et al (2017). Biodiversity losses and conservation responses in the Anthropocene. Science 356: 270-275.

Juffe-Bignoli, D., Burgess, N. D., Bingham, H., Belle, E. M. S., et al (2014). Protected Planet Report 2014. Tracking progress towards global targets for protected area. UNEP-WCMC: Cambridge, United Kingdom, $70 \mathrm{p}$

Kenkel, N. C. and Orloci, L. (1986). Applying metric and nonmetric multidimensional scaling to ecological studies: some new results. Ecology 67: 919-928.

Khan, M. S. and Bhagwat, S. A. (2010). Protected areas: A resource or constraint for local people? A study at Chitral Gol National Park, North-West Frontier Province, Pakistan. Mountain Research and Development 30: 14-24.

Klain, S. C., Olmsted, P., Chan, K. M. A., and Satterfield, T. (2017). Relational values resonate broadly and differently than intrinsic or instrumental values, or the new ecological paradigm. PLoS ONE 12(8): e0183962.

Leigh, P. (2005). The ecological crisis, the human condition and community-based restoration as an instrument for its cure. Ethics in Science and Environmental Politics: 3-15.

Lewicka, M. (2011). Place attachment: How far have we come in the last 40 years? Journal of Environmental Psychology 31(3): 207-230.

Lockwood, M., 2010. Good governance for terrestrial protected areas: a framework, principles and performance outcomes. Journal of Environmental Management 91, 754-766.
Lyver, P. O’B, Davies, J., and Allen, R. (2014). Settling indigenous claims to protected areas: weighing Māori aspirations against Australian experiences. Conservation and Society 12(1): 89-106.

Lyver, P. O'B., Akins, A., Phipps, H., Kahui, V., Towns, D. R., and Moller, H. (2016). Key biocultural values to guide restoration action and planning in New Zealand. Restoration Ecology 24(3): 314-323.

Maffi, L. and Woodley, E. (2010). Biocultural diversity conservation: a global sourcebook. Earthscan, London, United Kingdom, 282 p.

Mannetti, L. M., Göttert, T., Zeller, U. and Esler, K. J. (2019). Identifying and categorizing stakeholders for protected area expansion around a national park in Namibia. Ecology and Society 24(2): 5.

McDermott, M. H., Mahanty, S., and Schreckenberg, K. (2012). Examining equity: a multidimensional framework for assessing equity in payments for ecosystem services. Environmental Science Policy 33: 416-427.

McNeill, J. (2016). Different meanings of 'nature' for New Zealand's conservation institutions. Policy Quarterly 12(1).

Millennium Ecosystem Assessment (MEA) (2005). Millennium Ecosystem Assessment. Ecosystems and human well-being: synthesis. Island Press, Washington, DC, USA.

Molloy, L. (2015). Protected areas - New Zealand's protected areas, Te Ara - the Encyclopedia of New Zealand, http://www.TeAra.govt.nz/ en/protected-areas/page-1. Accessed 25 May 2018).

Nepal, S. K. (2002). Involving Indigenous Peoples in Protected Area Management: Comparative Perspectives from Nepal, Thailand, and China. Environmental Management 30: 748-763.

Neumann, R. P. (1997). Primitive ideas: protected area buffer zones and the politics of land in Africa. Development and Change 28: 559582.

New Zealand Government (2014). Te Urewera Act 2014. Public Act No. 51, Parliamentary Counsel Office, Wellington, New Zealand, $144 \mathrm{p}$.

Nursey-Bray, M. and P. Rist. (2009). Co-management and protected area management: achieving effective management of a contested site, lessons from the Great Barrier Reef World Heritage Area (GBRWHA). Marine Policy 33: 118-127.

Oksanen, J., Blanchet, F. G., Friendly, M., Kindt, R., et al (2019). vegan: Community Ecology Package. R package version 2.5-5. https:// CRAN.R-project.org/package=vegan

Oldfield, S. (1988). Buffer zone management in tropical moist forests: case studies and guidelines. IUCN, Gland, Switzerland.

Olson, J.M. and Zanna, M.P. (1993). Attitudes and attitude change. Annual Review of Psychology 44: 117-154.

Phipps, H. Akins, A., Moller, H., Lyver, P.O'B., Kahui, V. and Towns, D. (2011). Cross-cultural values for restoring coastal forest ecosystems in New Zealand. Landcare Research Report: LC 243, 134 p.

Poirier, R. and Ostergren, D. (2002). Evicting people from nature: Indigenous land rights and national parks in Australia, Russia, and the United States. Natural Resources Journal 42: 331-351.

R Core Team (2017). R: A language and environment for statistical computing. R Foundation for Statistical Computing, Vienna, Austria. https://www.R-project.org/.

Rights and Resources Initiative (2015). Who owns the worlds' land? A global baseline of formally recognized indigenous and community land rights. RRI, Washington DC, USA, $44 \mathrm{p}$.

Roe, D. (2008). The origins and evolution of the conservation poverty debate: a review of key literature, events and policy processes. Oryx 42: 491-503.

Rokeach, M. (1973). The nature of human values. Free Press, New York, USA.

Ruru, J., 2004. Indigenous peoples' ownership and management of mountains: the Aotearoa/New Zealand experience. Indigenous Law Journal 3: 111-137.

Ruru, J. (2008). A Māori right to own and manage national parks? Journal of South Pacific Law 12: 105-110. 
Ruru, J. (2012). Settling Indigenous place: Reconciling legal fictions in governing Canada and Aotearoa-New Zealand's National Parks. Faculty of Law, University of Victoria, Canada, 388 p.

Ruru, J. (2014). Tūhoe-Crown settlement - Te Urewera Act 2014. Retrieved from http://maorilawreview.co.nz/2014/10/Tūhoecrown-settlement-te-urewera-act-2014/

Ruru, J., Lyver, P. O’B., Scott, N., and Edmunds, D. (2017). Reversing the decline in New Zealand's biodiversity: Empowering Māori within reformed conservation law. Policy Quarterly 13: 65-71.

Safi, M. (2017). Ganges and Yamuna rivers granted same legal rights as human beings. The Guardian. Accessed 5 September 2020: https:// www.theguardian.com/world/2017/mar/21/ganges-and-yamunarivers-granted-same-legal-rights-as-human-beings.

Saldana, J. (2016). The coding manual for qualitative researchers (3 Ed.), London: SAGE.

Sanders, K. (2017). 'Beyond human ownership'? Property, power and legal personality for nature in Aotearoa New Zealand. Journal of Environmental Law 30: 207-234.

Scannell, L. and Gifford, R. 2010. Defining place attachment: A tripartite organizing framework. Journal of Environmental Psychology 30: 1 -10 .

Schultz, L., Duit, A., and Folke, C. (2011). Participation, adaptive comanagement, and management performance in the world network of biosphere reserves. World Developement 39: 662-671.

Schwartz, S. H., Cieciuch, J., Vecchione, M., Davidov, E., et al (2012). Refining the theory of basic individual values. Journal of Personality and Social Psychology 103(4): 663-688.

Secretariat of the Convention on Biological Diversity (2008). Protected areas in today's world: their values and benefits for the welfare of the planet. Technical Series No. 36, Montreal, Canada, $96 \mathrm{p}$.

Sikor, T., Adrian Martin, A., Fisher, J., and He, J. (2014). Toward an empirical analysis of justice in ecosystem governance. Conservation Letters, 7: 524-532.

Stedman, R. C. (2002). Toward a Social Psychology of Place: Predicting Behavior from Place-Based Cognitions, Attitude, and Identity. Enviornmental Behaviour 34(5): 561-581.

Sterling, E. J., Betley, E., Sigouin, A., Gomez, A., et al (2017). Assessing the evidence for stakeholder engagement in biodiversity conservation. Biological Conservation 209: 159-171.

Stewart, W.P., Liebert, D., Larkin, K.W. (2004). Community identities as visions for landscape change. Landscape and Urban Planning 69: 315-334.

Stolton, S., Dudley, N., Avcıŏ̆lu Çokçalıșkan, B., Hunter, D., Ivanić, K.Z., Kanga, E., Kettunen, M., Kumagai, Y., Maxted, N., Senior, J., Wong, M., Keenleyside, K., Mulrooney, D., Waithaka, J. (2015) Values and benefits of protected areas, in G. L. Worboys, M. Lockwood, A. Kothari, S. Feary and I. Pulsford (eds) Protected
Area Governance and Management, pp. 145-168, ANU Press, Canberra, Australia.

Stone, C. D. (1972) Should trees have standing - Toward legal rights for natural objects. Southern California Law Review 45: 450-501.

Studley, J. and Bleisch, W. (2018). Juristic personhood for sacred natural sites: a potential means for protecting nature Parks, 24: 81-96.

Te Urewera Board (2017). Te Kawa o Te Urewera, Tāneātua, New Zealand, $119 \mathrm{p}$.

Tengö, M., Brondizio, E. S., Elmqvist, T., Malmer, P., et al (2014). Connecting diverse knowledge systems for enhanced ecosystem governance: the multiple evidence base approach. Ambio 43: 579 591.

The New Zealand Parliamentary Counsel Office (2016). Te Awa Tupua (Whanganui River Claims Settlement) Bill, The New Zealand Parliamentary Counsel Office, Wellington, New Zealand.

Timoti, P., Lyver, P.O'B., Matamua, R., Jones, C.J. and Tahi, B.L. (2017). A representation of a Tuawhenua worldview guides environmental conservation. Ecology and Society 22(4): 20.

Van den Born, R.J.G., Arts, B., Admiraal, J., et al. (2018). The missing pillar: Eudemonic values in the justification of nature conservation. Journal of Environmental Planning and Management, 61: 841-856.

Waitangi Tribunal (2018). Retrieved 5 November 2018, from https:// www.waitangitribunal.govt.nz/about-waitangi-tribunal/

West, P., Igoe, J., and Brockington, D. (2006). Parks and peoples: the social impact of protected areas. Annual Review of Anthropology 35: 251-277.

Wilshusen, P. R., Brechin, S. R., Fortwangler, C. L., and West, P. C. (2002). Reinventing a square wheel: critique of a resurgent "protection paradigm" in international biodiversity conservation. Society and National Resources 15: 17-40.

Young, J. C., Jordan, A., Searle, K. R., Butler, A., et al (2013). Does stakeholder involvement really biodiversity conservation? Biological Consrvation 158: 359-370.

Zafra-Calvo, N., Garmendia, E., Pascual, U., Palomo, I., et al. (2019). Progress toward equitably managed protected areas in Aichi Target 11: a global survey. BioScience, 69: 191-197.

Zeller, U., Starik, N. and Göttert, T. (2017). Biodiversity, land use and ecosystem services An organismic and comparative approach to different geographical regions. Global Ecology and Conservation 10: $114-125$.

Zorondo-Rodríguez, F., Díaz, M., Simonetti-Grez, G. and Simonetti, J. A. (2019). Why would new protected areas be accepted or rejected by the public?: Lessons from an ex-ante evaluation of the new Patagonia Park Network in Chile. Land Use Policy 89: 104248.

Publisher's Note Springer Nature remains neutral with regard to jurisdictional claims in published maps and institutional affiliations. 